\title{
Influence of Dangerous Meteorological Phenomena on the Emergence of Erosional forms of Relief Taking Into Account Changes in the Biodiversity of Vegetation Communities in Eastern Siberia
}

\author{
Yuriy V. Zima ${ }^{1}$ and ID Liya N. Zima ${ }^{2}$ \\ IInstitute of Natural Resources, Ecology and Cryology, SB RAS \\ ${ }^{2}$ Transbaikal State University
}

\begin{abstract}
The urgency of the problem is caused by the lack of data on the formation, morphology, dynamics, features of ravine development in mountain relief, contrast of natural conditions and landscapes of areas of Eastern Siberia. The aim of the work is to study the dynamics of development of gullies under the influence of dangerous meteorological phenomena in the territories of the forest natural zone in the mountain and foothill areas of pine and larch forests in the territory of Eastern Transbaikalia. For the research, an experimental station was selected on the slope of a pine forest after wildfires, where field surveys of the ravine-gully system with the use of instrumental surveys were carried out. The analysis of data obtained from field studies and space images made it possible to identify the basic morphometric parameters of four ravines at different stages of their development and construct a model of a ravine-gully network. In addition, the floristic composition of the surveyed area was studied, represented by a small number of grasses, bushes and trees; the soil cover of gullies is represented mainly by eroded rocks: sandstones and sandy loams. The materials of the article can be useful to geographers, geomorphologists, ecologists, biologists when drawing up plans for the economic use of the territory, counter-erosion measures, when designing road transport routes for determining areas of increased danger of development of ravine erosion, when allocating recreational areas or nature protection zones.
\end{abstract}

Keywords: ravine formation, ravine, dangerous meteorological phenomena, biodiversity, Eastern Transbaikalia

\section{Introduction}

"Ravine erosion is an active relief-forming process caused by temporary channel flows of rain and melted water, as a result of which specific linear forms appear on the land surface. The direct cause of the ravine formation is a violation, under any types of economic use of lands, of the natural conditions for the formation of water runoff on the slopes of river valleys, beams, dry lands, etc." [1]. Despite the fact that ravine erosion has been studied for a long time and many articles have been published on this issue [2-8], the interest in ravine formation is growing now, which is connected with the ecological focus of modern studies of linear erosion, with the study of regions not investigated in this respect, as well as with the use of new types of measuring equipment, the use of GIS-technologies, etc. [9-20].

The main natural factors in ravine formation are periodically occurring dangerous meteorological phenomena and natural fires, which (within a different period of time) can radically transform the landscape. By the degree of influence on the relief in the space-time mode, these phenomena are subdivided into the following types:

- extremely dangerous - the changes occur within a short period of time (minutes, hours, days).

- dangerous -the changes occur within a relatively short period of time (month, season, year).

- slowly dangerous -the changes occur within a long period of time (a multi-year period).

Extremely dangerous meteorological phenomena include short-term showers, rainfall, radical warming, anthropogenic discharge of water. The dangerous phenomena include the maximum rainfall for the month or for the season of the year, which, as a rule, takes place during the warm period of the year; abundant snowfall, which, when melting, can lead to the first type of phenomena; mudflows. In addition, the second type can include wet years, when the amount of precipitation exceeds the average value. The term "slowly dangerous" can be attributed to the phenomena occurring over a long period of time, such as climate warming, the high water hydrological period. Each of the listed dangerous meteorological phenomena plays an active role in the process of ravine formation and has an impact on the development of

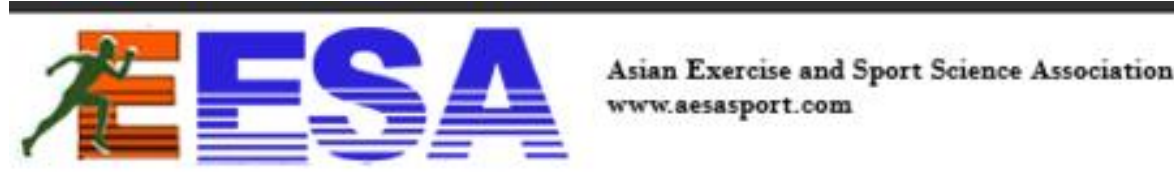


erosion processes.

The purpose of the work is to track changes in the structure and dynamics of the development of erosion forms, by the example of ravine formation, under the influence of hazardous meteorological phenomena, taking into account the change in the biodiversity of plant communities in the territories of the Eastern Transbaikalia forest zone.

\section{Materials and methods}

In the process of collecting and analyzing materials on the development of linear negative forms of relief (ravine formation), the following geographic research methods were used: comparative geographic, expeditionary, laboratory, stationary methods and the method of remote sensing of the Earth.

For this purpose, the following studies were carried out:

- study of meteorological data related to ravine formation;

- field surveys of ravine-gully systems in key areas impacted by forest fires with the use of instrumental surveys;

- study of the ravine development dynamics on the experimental stationary site, which allowed obtaining the basic morphometric parameters of gullies at different stages of development, and also to trace and compare the changes in space parameters of gullies;

- field observations of the formation of water and sediment runoff in gullies on the experimental stationary site, providing data on the hydrological characteristics of streams.

\section{Results and discussion}

The research areas are located in mountain-taiga larch and pine landscapes of the Zabaikalye Territory of Eastern Siberia. The area of pine forests under study is located in the valley of the Ingoda River belonging to the Amur basin; the area of larch forests under study is located in the valley of the Khilok River, which belongs to the Baikal basin. The height of the survey area above sea level varies from 700 to $1100 \mathrm{~m}$. Both territories are geomorphologically different. Studies have shown that ravines in these territories are at different stages of development and their formation takes place in different conditions.

The emergence and intensity of the development of ravine forms is determined not only by the complex of natural characteristics of the territories (relief, climate, soils, soil, vegetation cover), but also by anthropogenic influence (creation of additional drainage boundaries that concentrate streams of thawed and rainwater, redistribution of runoff in the catchment area, the decrease of the filtration ability of soils, disturbance of natural vegetation, etc.).

Unconditional influence on the formation of ravines is caused by climatic conditions, in particular, showers or heavy rains, which are extremely dangerous meteorological phenomena. In the Zabaikalye Territory, the maximum liquid precipitation, which makes $70 \%$ from the total, mainly occurs in the second half of the summer period (Figure 1). The immediate effect on erosion processes is produced by the amount of precipitation, its distribution by months, daily maximums, duration, intensity, as well as the time of precipitation. According to the meteorological station of Chita, during a long observation period from 1934 to 2017 , the average annual maximum precipitation is typical for July (up to $98 \mathrm{~mm}$ ) and August (up to 83 $\mathrm{mm}$ ). When rain falls, the soil does not have time to absorb moisture, excess water flows down the slopes, creating erosion forms (gullies, ruts, ravines). During showers or heavy rains exceeding $30 \mathrm{~mm} / \mathrm{h}$, in a few hours there emerge ravines up to 200-300 m long, with the depth reaching 3-5 $\mathrm{m}$. The eroding stream of water carries in itself a huge amount of sediment that forms alluvial cones at the end of the ravine.

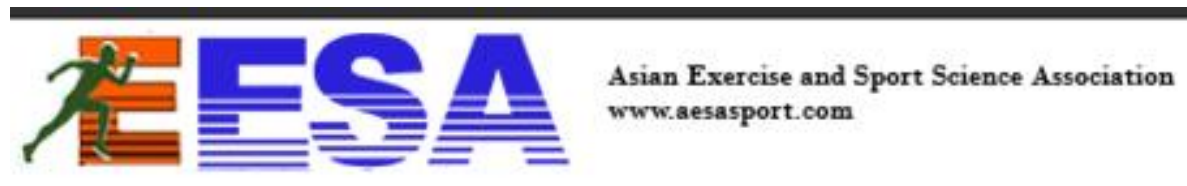




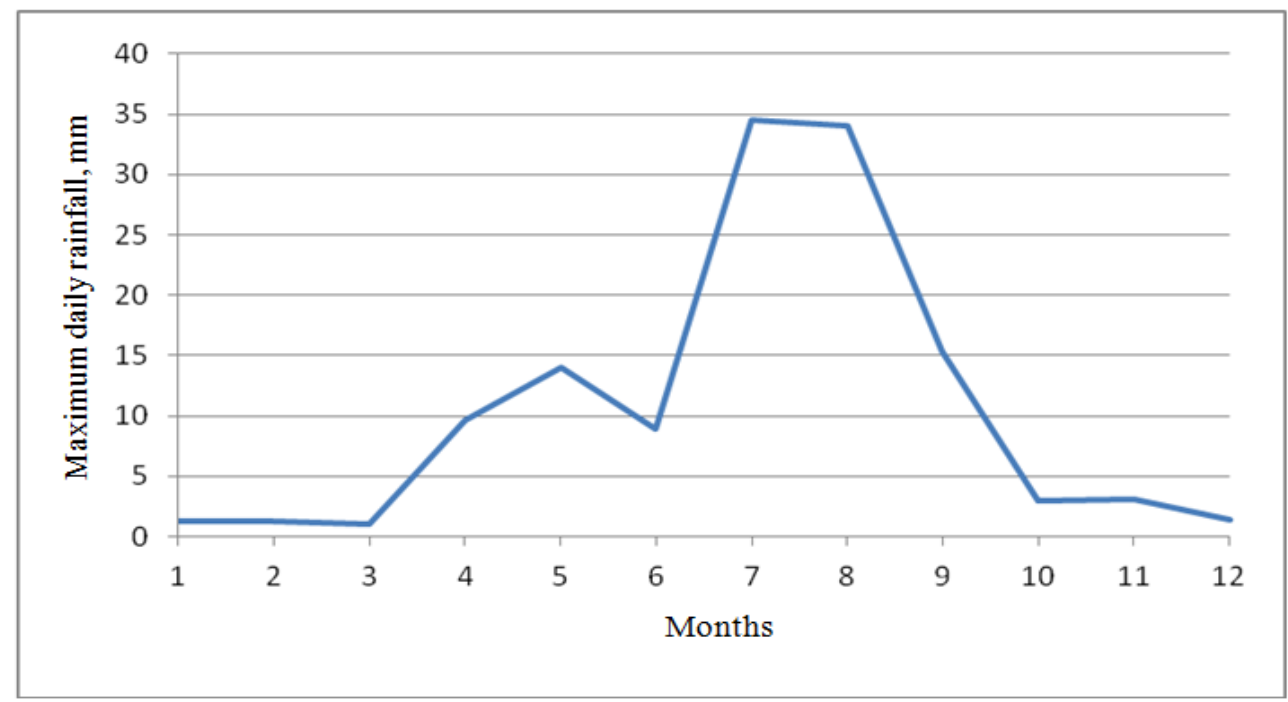

Fig.1. Maximum daily rainfall for the year (meteorological station of Chita)

Meteorological conditions, namely high temperatures, lack of precipitation or small amounts of precipitation, low humidity, strong winds, and thunderstorms are factors of forest fire danger. Over the past 10 years, in most of the Zabaikalye Territory, there has been an increase in the number of forest fires and areas impacted by fires, due to increased aridity of the climate. In addition, the anthropogenic factor contributes to the emergence of fires (uncontrolled agricultural arsons in the spring and autumn periods: burning grass on hayfields and pastures, careless handling of fire, lighting bonfires when visiting the forest, littering the forest with bottles and glass fragments that can work like lenses when bright sunlight, etc.). Forest fires, passing large areas of the earth's surface, destroy vegetation, bare the soil cover and contribute to the development of water erosion. As a result, the landscape is geomorphologically altered; ruts and rills appear (Photo 1).

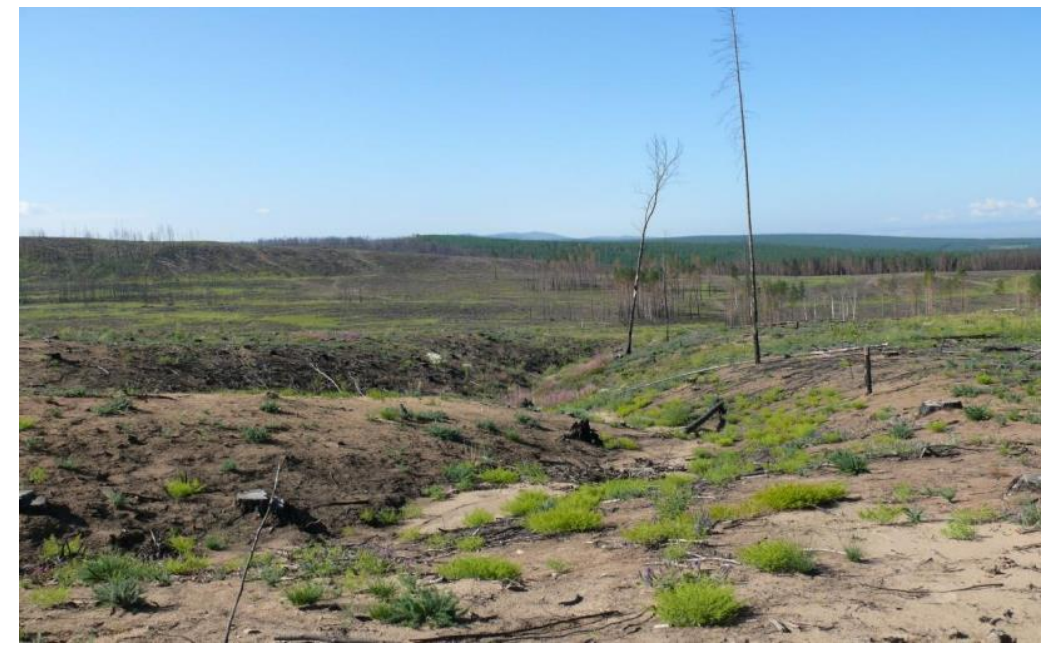

Photo 1. Areas impacted by wildfires (photo by Yu.V. Zima)

By the amount of gullies, the areas of scientific research can be divided into two types. The first includes pine forests, where the ravine-gully network is activated, which is facilitated by anthropogenic development of land and destruction of forests by forest fires. The ravine-gully network is represented by more than 50 gullies -0.05 units $/ \mathrm{km}^{2}$, occupying an area of $100 \mathrm{~km}^{2}$. The second type includes the territories covered with

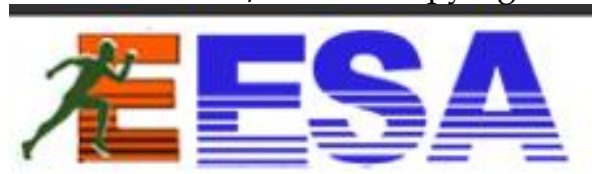

Asian Exercise and Sport Science Association

www.aesasport.com 
larch forests, where gullies are rare and only single forms are represented, no more than 10 gullies on an area of $100 \mathrm{~km}^{2}-0.01$ units $/ \mathrm{km}^{2}$.

Figure 2 shows satellite images showing the formation of the ravine-gully network on the slope of a pine forest after wildfires have passed $87 \mathrm{~km}^{2}$. The soil cover is represented mainly by eroding formations: sandstones and sandy loams.

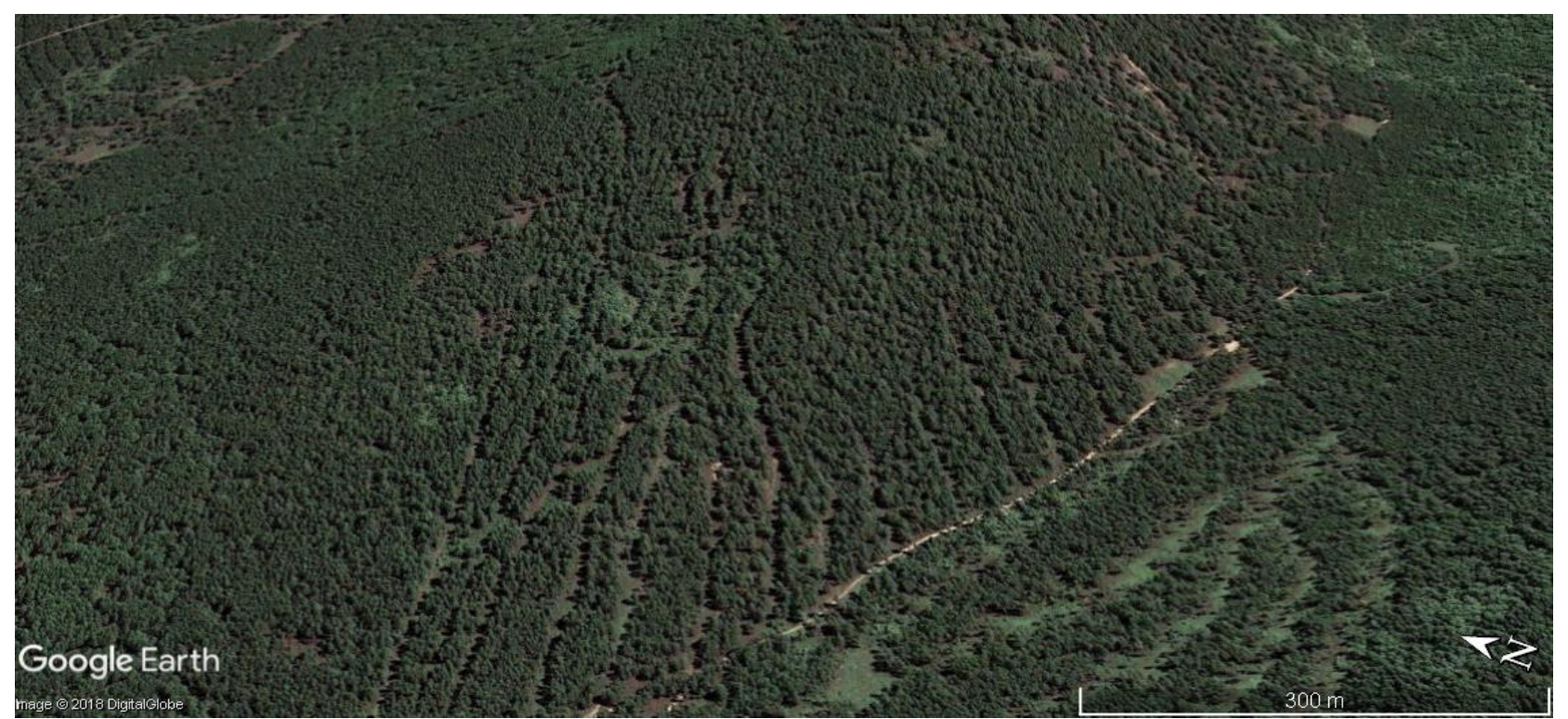

A

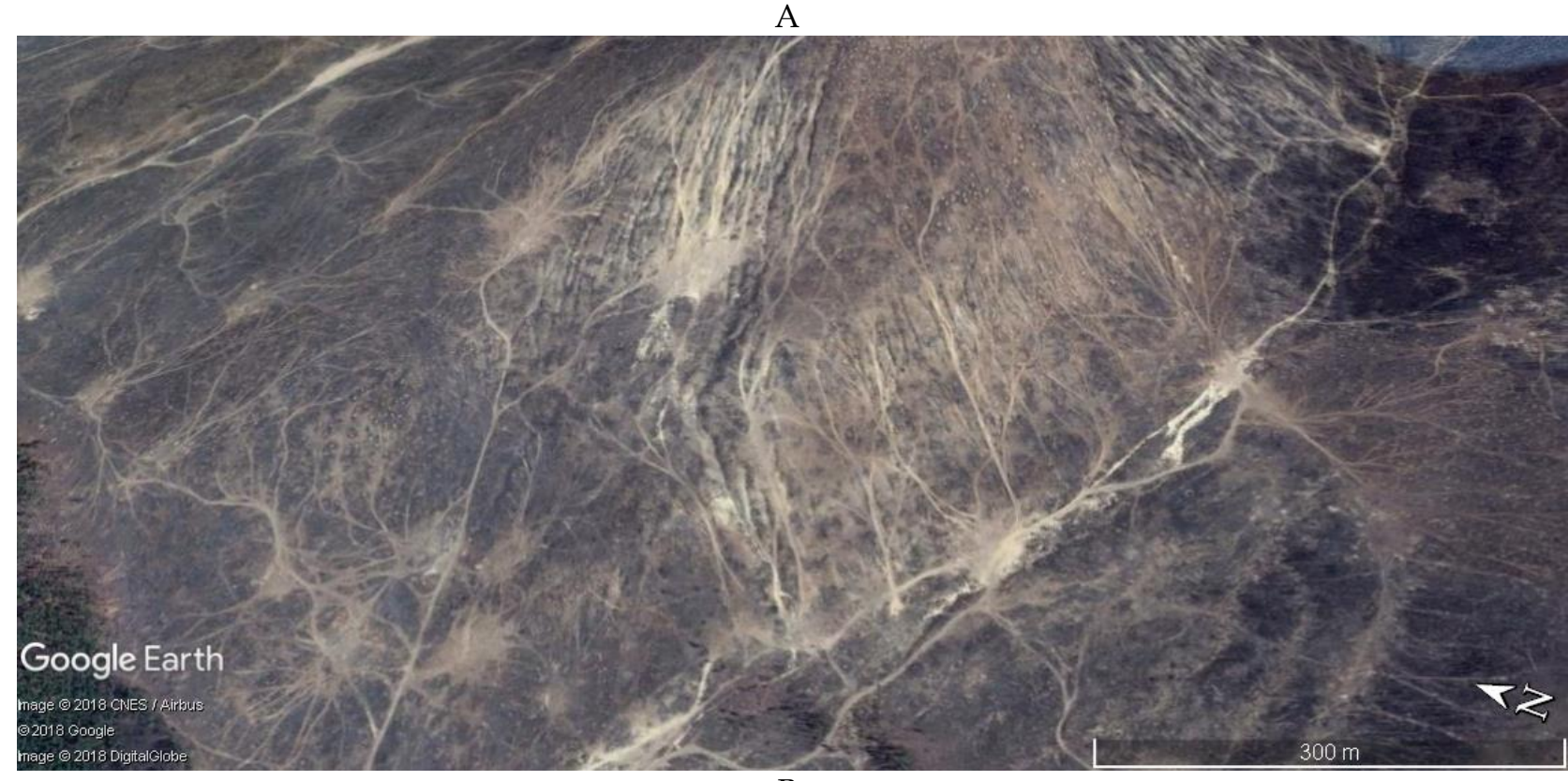

B

Fig. 2. Space images of the territory of the study: A - Territory before fires (2009) B - The formation of a ravine-gully network after forest fires (2015)

Fig. 2. The formation of a ravine-gully network after forest fires (2015)

An experimental station was selected to observe the formation of the runoff and the change of the morphometric characteristics of the ravines. In this section of the ravine-gully network, 10 morphostratches were identified, which pass from a fixed landmark in a cross section along four ravines.

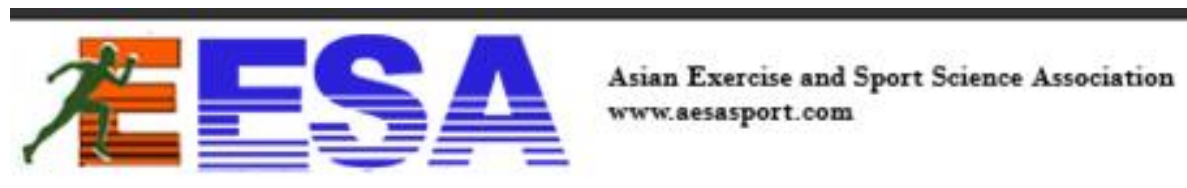


According to the relief, the ravines belong to the mountainous or slope type, where there is a precipitous ledge of thalweg in the upper part of the ravine. The transverse profile of ravines is $\mathrm{V}$-shaped. In this case, the origin of the gullies is natural-anthropogenic, since the erosion forms emerged as a result of the construction of forest roads on the slopes, which in turn led to a change in the flow of surface waters.

In the stationary research, photographs of ravines were taken, the measurement of their length, width and depth in different parts, and height of the summit ledge was performed (Photo 2). The length of the most developed ravine was $161 \mathrm{~m}$, the length of the longest ravine in the development stage was over $200 \mathrm{~m}$. There are short ravines where the stream of water merges into another ravine, which contributes to a greater erosion into the depth and width of the next ravine. The ravine, in which many water flows merge, develops strongly, the flow of soil particles increases, which creates a large alluvial cone of in the mouth.
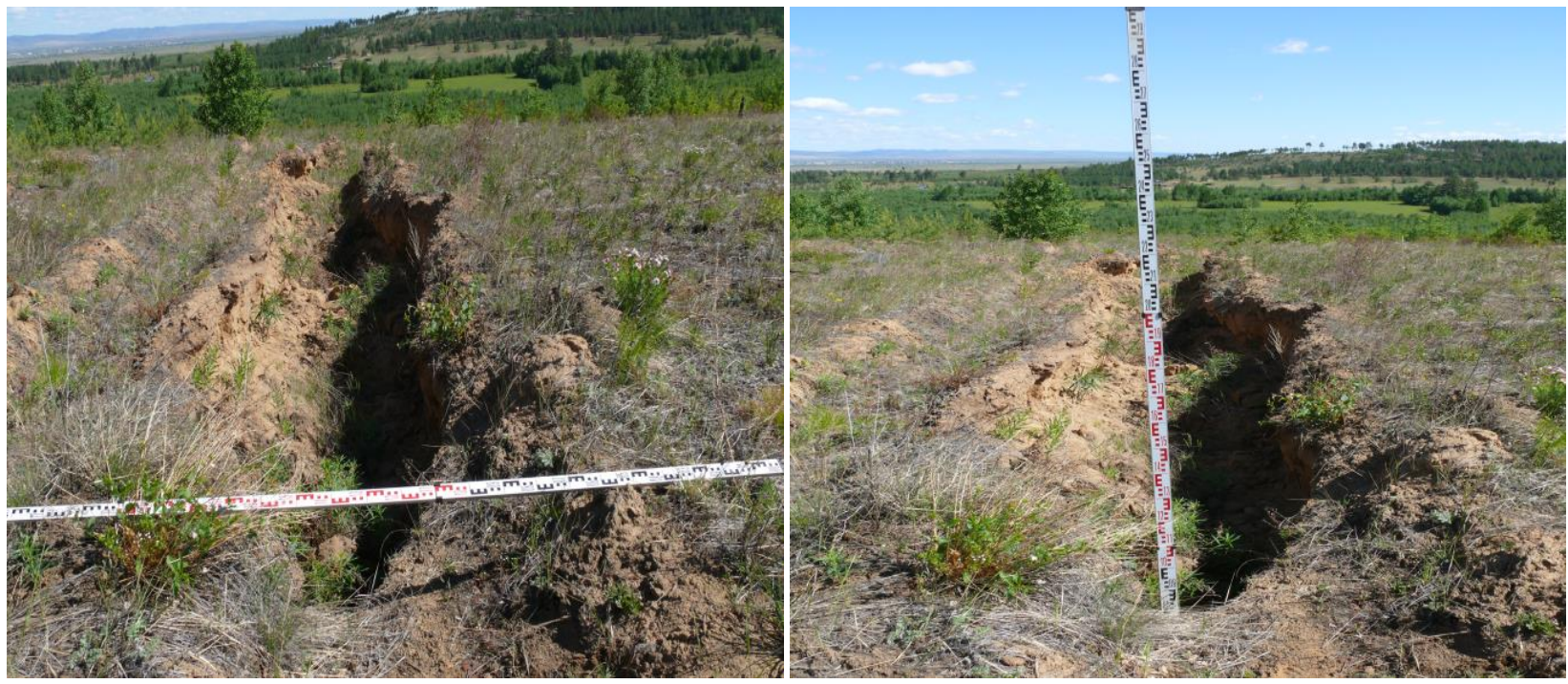

Photo 2. Study of the ravine morphology

Space images of different years have made it possible to trace the dynamics of the ravine development. In 2004, the length of the ravine was $157 \mathrm{~m}$, the width along the entire length was from 1 to 3.5 $\mathrm{m}$. In 2016, the length of the ravine is $161 \mathrm{~m}$, the width at the top was 7-8 $\mathrm{m}$, the width in the mouth - 3-4 $\mathrm{m}$. In 12 years the length of the ravine increased by $4 \mathrm{~m}$, the width - by $2-4 \mathrm{~m}$. The development of the riverbed and erosion of the slopes of the ravine amounted to an average of $0.33 \mathrm{~m}$ per year.

Important factors in the formation of ravines are the steepness of the slope, which ranges from 7 to 20 $\%$, and the soil cover, which is mainly composed of sands, sandy loams. According to laboratory tests, the granulometric composition of soils is mainly represented by sands (from fine to coarse sand) with a diameter of $0.05-1.0 \mathrm{~mm}$.

The active development of the ravine-gully network on the slope was caused by dangerous meteorological conditions - showers with a maximum intensity of 1 to $2 \mathrm{~mm}$ per minute, with a total level of more than $25 \mathrm{~mm}$. The erosion forms emerged at once, and then during the year the form of the ravine changed towards the increase of length, width and depth.

The erosion of ravines is caused by temporary channel flows from different areas, with extremely variable characteristics of the slopes' mean and local values, runoff lengths, depths of erosion bases, the type of surface cover, and the filtration characteristics of soils[11].

The formation of the stream network on the slopes is one of the forces of erosion and transformation of the ravine relief [16]. Studies of flows have shown that erosion mainly occurs at a flow velocity of $0.20-0.70$ $\mathrm{m} / \mathrm{s}$. The roughness coefficient is 0.0025-0.0045, the Reynolds number - 8000-35000, the Froude number 0.50-1.50. Streams of water flow almost along the slope, they can slightly deviate from the route, avoiding obstacles in the form of stones. The erosion of soil causes the formation of rapids on the slope, which

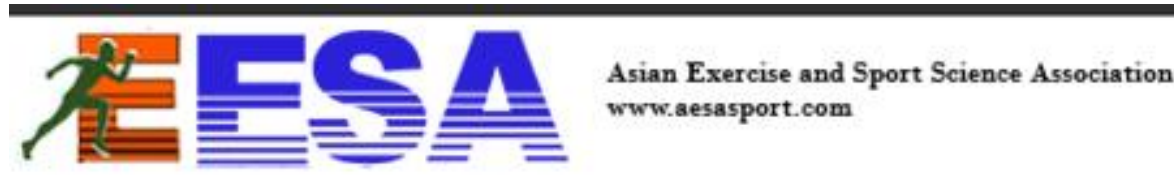


contribute to an increase in the flow speed. As a result, the longitudinal profile of the slope shows a stepped relief.

In the process of formation, ravines pass several stages. At the first stage of erosion, a ridge (rut) is formed on a steep slope. It is triangular in shape, parallel to the surface of the slope. At the second stage, the ravine becomes deeper with a decrease in the longitudinal slope of the bottom. A sharp precipice forms at the edge. The ravine expands and acquires a trapezoidal shape in the cross section. By the end of the second stage, a smooth longitudinal profile is produced at the bottom of the ravine, while at the mouth of the ravine, where water loses its speed, a cone of alluvial sediment is formed. At the third stage, a further growth of the ravine takes place towards the watershed and its cross-section widens as a result of the washing and shedding of the banks. On the lateral thalwegs, along which water flows to the ravine from the secondary basins, branching ravines -or branches - begin to form. The ravine continues to develop until it reaches ground layers that do not yield to erosion, or until the basin that feeds it does not decrease near the watershed to such an extent that erosion stops. At the fourth stage, deep erosion and washout of the banks gradually cease; the ravine ceases to grow. The slopes take a stable outline and overgrow with grass. The ravine turns into a gully.

Figure 3 shows the model of the ravine-gully system. The diagram shows 4 ravines, each of them at a different stage of development. The first one is a developing ravine, the second one is already developed, in the third and fourth erosion is slowing down.

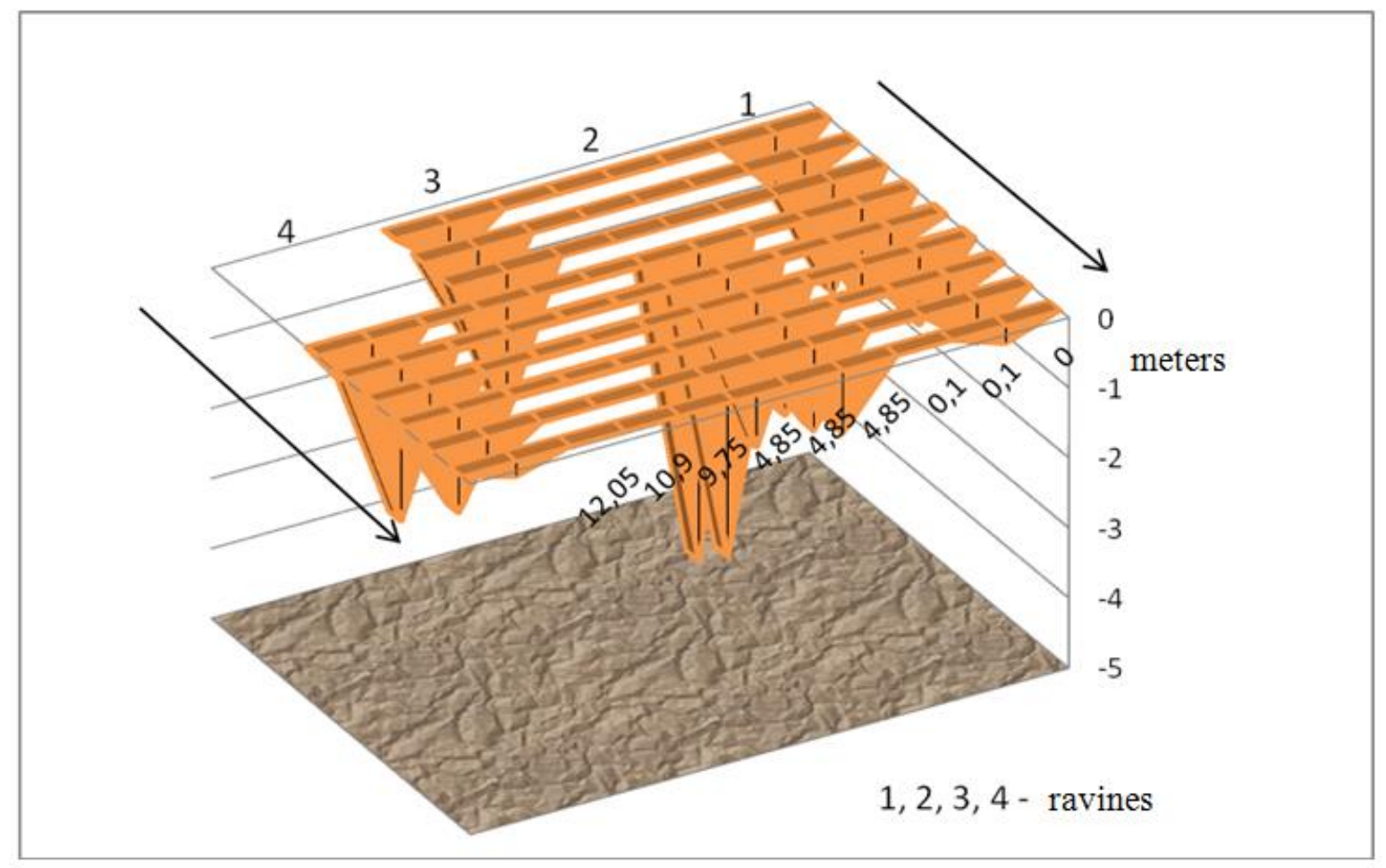

Fig. 3. Ravine-gully study model

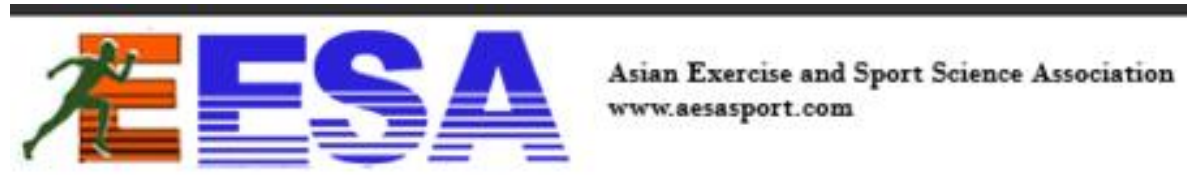


However, after extensive forest fires, the development of ravines can resume again, as the slopes of the gullies are bared and after intensive rainfall or snowmelt, active erosion of the soil occurs and favorable conditions for the further development of erosion processes are created. It is according to this scheme that the process of ravine formation is resumed on the slopes of pine and larch forests on the territory of the Eastern Transbaikalia.

A series of forest fires that occurred after 2004 had a significant impact on the level of forest biodiversity. As a result, the forest cover of the territory has decreased from $92.2 \%$ to $52.6 \%$. Currently, the share of burnt forest is more than $50 \%$. The main share of the timber stock was made up by pine (78\%), larch, birch $(10 \%$ each), and aspen $2 \%$. Taking into account the change in the forest cover of the study area, the timber reserves have decreased from $1.361 .600 \mathrm{~m}^{3}$ to $776.700 \mathrm{~m}^{3}$.

When studying ravine erosion on the slopes of pine and larch forests, research was carried out on the vegetation of ravines. The total coverage of grasses was 20-30\% with an average height of $80 \mathrm{~cm}$. The vegetation of ravines has poor species composition. Wood forms are represented by birch, aspen, poplar, pine, larch; shrubs are represented by willow, rhododendron; grass - by willow-herb, rump, reed, etc. The covering of ravines by grass is very slow, and in some cases the vegetation cannot be fixed in the ground, the plant seeds are either washed out by the water flow, or blown out by the wind, or freeze in the cold period of the year.

Table 1. The vegetation of ravines.

\begin{tabular}{|c|c|c|c|}
\hline Name of the plant & Number & Name of the plant & Number \\
\hline \multicolumn{2}{|c|}{ Trees (saplings) } & \multicolumn{2}{|l|}{ Grasses } \\
\hline Betulapendula $(\mathbf{0 , 6} \boldsymbol{\mathbf { M }})$ & 1 & Dendranthemumzawadskii & $2-3$ \\
\hline Larixgmelinii $(\mathbf{0}, \mathbf{6} \boldsymbol{M})$ & 1 & Viciaunijuga & $2-3$ \\
\hline Populustremula $(\mathbf{1}, \mathbf{5} \mathbf{M})$ & $2-3$ & Chamaenerionangustifolium & $5-10$ \\
\hline Pinussylvestris $(\mathbf{0}, \mathbf{2 - 0}, \mathbf{4} \boldsymbol{M})$ & $2-3$ & Chamaenerionangustifolium & $5-10$ \\
\hline Populussuaveolens (2м) & 1 & Lupinasterpentaphyllus & $2-3$ \\
\hline Malusbaccata $(\mathbf{1}, \mathbf{5 M})$ & 1 & Bromopsissibirica & $10-20$ \\
\hline \multicolumn{2}{|l|}{ Bushes } & Sanguisorbaofficinalis & $2-3$ \\
\hline Salixbebbiana & 1 & Polygonatumhumile & $2-3$ \\
\hline Salixschwerinii & 1 & Potentillasemiglabra & 1 \\
\hline Rhododendrondauricum & 1 & Festucalenensis & $2-3$ \\
\hline \multicolumn{2}{|l|}{ Grasses } & Carexpediformis & $2-3$ \\
\hline Astragalusmembranaceus & 1 & Oxytropismyriophylla & $2-3$ \\
\hline Calamagrostisepigeios & $2-3$ & Sedumaizoon & $2-3$ \\
\hline Heteropappusbiennis & $2-3$ & & \\
\hline
\end{tabular}

\section{Conclusion}

When studying the development of ravine formation under the influence of dangerous meteorological phenomena, taking into account studies of the overgrowing of ravines by vegetation, the structure and dynamics of ravines development on the territories of pine and larch forest zone in Eastern Transbaikalia have been identified. On the territories of pine forests the ravine-gully network develops more actively than on the territories covered with larch forests. Steep slopes, easy erosion of soil, heavy showers, and absence of leaf cover of the tree tops after fires promote the activation of ravine formation. In order to trace the dynamics of ravine development under the influence of dangerous meteorological phenomena taking into account the change in the biodiversity of plant communities, an experimental stationary site was selected to monitor the development of four ravines. Each of them is at a different stage of development. The first one is a developing ravine, the second one is already developed, in the third and fourth erosion is slowing down.

Space images and field measurements have made it possible to obtain the main morphometric parameters of ravine development. On the basis of the morphometric parameters, the model of ravine-gully system was developed. The development of the riverbed and erosion of the slopes of the ravine amount to an average of $0.33 \mathrm{~m}$ per year with the granulometric composition of soils with a diameter of $0.05-1.0 \mathrm{~mm}$.

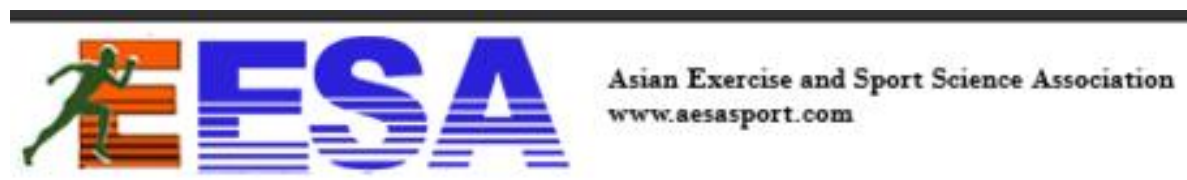


The study of the vegetation composition of the ravines showed that their overgrowth is very slow and the vegetation is represented by an insignificant number of species. After forest fires, the surfaces of gullies are bared and the development of ravine is renewed.

\section{References}

1. Zorina, E.F. Ovrazhnaya erosion: regularities and development potential. - Moscow: GEOS. 2003. - 170 with.

2. Sobolev, S.S. The development of erosion processes on the territory of the European part of the USSR and the fight against them. M .; L .: Izd-vo AN SSSR, 1948. - T. 1. - 305 p.

3. Armand, D.L. Classification of erosion forms and processes // Questions of the methodology of soilerosion mapping. M., 1972. - P. 301-312.

4. Kosov, B.F., Lyubimov, B.P. Evaluation of deformation of ravine slopes by gravitational processes for forecasting the growth of ravines // Erosion of soils and channel processes. - Moscow: Izd-vo Mosk. University, 1979. - Issue. 7. - P. 90-100.

5. Makkaveev, N.I. Some features of the erosion-accumulative process // Erosion of soils and channel processes. - Moscow: Izd-vo Mosk. University, 1981. - Issue. 8. - P. 5-16.

6. Ravine erosion / B.F. Kosov, E.F. Zorina, B.P. Lyubimov et al. - Moscow: Izd-vo Mosk. University, 1989. $168 \mathrm{p}$.

7. Berkovich, K.M., Zorina, E.F., Litvinova, L.F. Ecological state and crisis changes in the erosion-and-river systems of Russia under the influence of anthropogenic loads // Universities of Russia. Geography. T. 1. - Moscow: Izd-vo Mosk. Un-ta, 1993. - P. 216-223.

8. Lyubimov, B.P. Zonal features of gully erosion // Geomorphology. - 1998. - No. 1. - P. 68-72.

9. Litvin, V.M., Trzhtsinsky, Yu.B. Interaction of complex geosystems and their significance for assessing geodynamic hazards of territories // Assessment and management of natural risks: Materials of the Obshcheros. Conf. RISK-2000. - M.: Ankil, 2000. - P. 95-99.

10. Belyaev, V.R., Golosov, V.N., Sidorchuk, A.Yu. and others. The use of radioisotopes for reconstruction of the stages of development of modern ravines / / Geomorphology. - 2005. - No. 1. - P. 31-44.

11. Zorina, E.F. Ovagogue is an independent direction of scientific research // Erosion of soils and channel processes. - M., 2008. - Issue. 16. - P. 92-101.

12. Litvin, L.F. To the estimation of the ratio of denudation in the main links of the erosion-channel systems of the East European Plain / / Twenty-third plenary interuniversity coordinated meeting on the problem of erosion, channel and wellhead processes. - Kaluga, 2008. - P. 18-27.

13. Bazhenova, O.I. Tendencies of changes in the regime of exogenous relief formation in the south of Siberia in the second half of the twentieth century // Geography and natural resources. - 2005. - No. 4. - P. 80-86.

14. Geography of gully erosion / Ed. E.F. Zorin. - Moscow: Izd-vo Mosk. University, 2006. - 324 p.

15. Ryzhov, Yu.V. Chronology of erosion-accumulative processes in the ravine-girder systems of the SouthWest Baikal region in the Holocene / / Geography and natural resources. - 2012. - No. 4. - P. 108-116.

16. Ryzhov, Yu.V. Formation of ravines in the south of Eastern Siberia. - Moscow: GEOS. 2015. - 178 pp.

17. Bierman P.R., Reuter J.M., Pavich M. et. al. Using cosmogenic nuclides to contrast rates of erosion and sediment yield in semi-arid, arroyo-dominated landscape, Rio Puerco Basin, New Mexico // Earth Surface Processes and Landforms. - 2005. - Vol. 30. No. 8. - P. 935-953.

18. Poesen J., Nachtergale J., Verstraeten G., Valentine C. Gully erosion and environmental change: importance and research needs / / Catena. - 2003. - Vol. 50. - P. 90-133.

19. Poesen J., Torri D., Vanwalleghem T. Gully erosion: procedures to adopt when modeling soil erosion in landscapes affected by gullying // Handbook of erosion modeling. - Blackwell Publishing Ltd. Chichester, UK, 2011. - Ch. 19. - P. 360-386.

20. Valentin C., Poessen J., Li Y. Gully erosion: impacts, factors and controls / / Catena. - 2005. - Vol. 63, No. 2-3. P. 132-153.

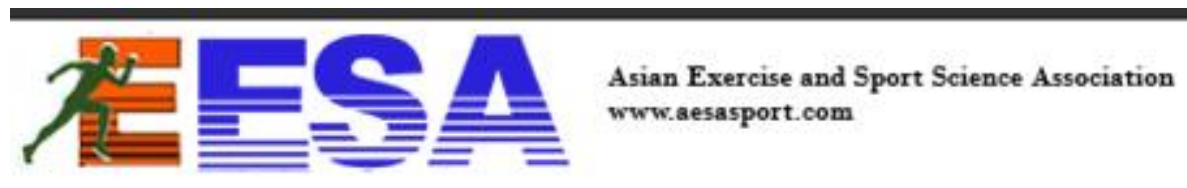

